\title{
THE REMEMBRANCE OF THE KATYŃ MASSACRE AND PRESIDENT LECH KACZYŃSKI'S CONCEPT OF POLISH-RUSSIAN RELATIONS [2005-2010]
}

\author{
by Patryk Wawrzyński
}

Lech Kaczyński's tragic death was a direct cause of the détente in PolishRussian relations, proclaimed by Prime Minister Donald Tusk and his Russian counterpart Vladimir Putin just after the Polish Air Force Tu-154 Crash. However this rapprochement is far from the political concept of the President. Considering the Polish internal debate on a proper form of Polish-Russian relations, I would like - in this short article to present a way as to how President Kaczyński understood challenges, that both nations have to pick up.

Taking advantage of an examination of narrations, and results of my two-year researche on cultural and mythical aspects of Kaczyński's political concept, I would like to present an influence of the Remembrance of the Katyn Massacre [in the wider perspective of Russian and Soviet crimes committed against the Polish Nation] on assumptions of a PolishRussian Reconciliation. In the first place I describe the inter-relation between the Past and the Present in Kaczyński's outlook, then I present his narrations about the Katyń Massacre and the Russian Expansionism. Afterwards I will present an influence of the Past on contemporary issues in Polish-Russian relations. 


\section{THE PERIODICITY OF THE HISTORY}

Understanding the Lot of the Nation as a recreation of an invariable events cycle is characteristic for President Lech Kaczyński's narrations about the Past. The recurrence of resistance, defiance against tyranny, and the struggle for national survival is - in Kaczyński's concept - substantiation for more then just a power game, the Periodicity means that the necessity of creating a strong and sovereign state becomes every generation's duty and a one and only chance to avoid a national disaster.

The zenith of the national Lot falls on the $20^{\text {th }}$ Century, when, as Kaczyński stated during the decoration of the 'Solidarity' activists in February 2010, consecutive generations have experienced "the captivity from occupiers, invaders, totalitarian ideologists, and public officers serving outside the Power's interests. [...] Repeatedly, there were attempts to capture from the Poles their identity, history, sense of their own human value, ownership, and the right to determine their own future"1. Polish national identity is hardly related to sacrifice, martyrdom, and the struggle against evil. Simultaneously, national history includes countless examples of heroism, triumph, and immortal successes, but at all times their achievements are endangered and impermanent.

Endeavors of foregoing generations become an inspirations for successive ones. Polish history is a relay race of - sometimes efficient, sometimes not - struggles against external Powers and desires for independence and state security. From the November Uprising 1830-1831, and the January Uprising 1863-1864, through the 1905 Revolution, and World War I, to the 1939 Defensive War, the Polish Underground State during World War II, the 'Cursed Soldiers' afterward, and the anticommunist opposition movements in the time of the People's Republic of Poland.

On the National Independence Day in 2007, posthumously decorating paramount 'cursed soldiers' Kazimierz Kamieński 'Huzar' [en. 'Hussar'], Władysław Łukasiuk 'Młot' [en. 'Hammer'], and Zygmunt Szyndzielarz

\footnotetext{
${ }^{1}$ Kancelaria Prezydenta RP [KPRP], List podczas odznaczeń w siedzibie NSZZ Solidarność, $8^{\text {th }}$ February 2010, http://www.prezydent.pl/archiwum/archiwum-aktualnosci/ [21.11.2011].
} 
'Łupaszka', Kaczyński emphasized that their heroic testimonies to patriotism were an inspiration for his generation to object durability of the Cold War order and to oppose the communist authority to rule Poland 2 .

Likewise, in December 2009, during the ceremony of unveiling the Memorial to the Victims of Communism in Łódź, Kaczyński appealed to the public, reminding that the inspiration of the underground resistance during World War II and afterward rose to sequential social spurts: the Poznan 1956 protests, the 1968 March events, the 1970 'Coastal' protests, the 1976 June protest, and finally the Birth of the 'Solidarity' social movement and its continuation during martial law and afterward, that together "lead us to cast off the communist yoke and regain our sovereign and democratic state" 3 .

The Periodicity of Polish history was the President's motivation to support the development of state' Politics of Memory, that - he hoped - would establish the tie between present-day society and the previous generations' heritage. Kaczyński mentioned it even in his 2008 New Year's Address, asking the Nation for common endeavors to raise welfare and secure Poland ${ }^{4}$. He believed that the Remembrance of History enables comprehending and a requirement of setting up an effective and modern state able to counteract and recover from a crisis.

On the eve of the $91^{\text {st }}$ Anniversary of Poland's assumption of independent statehood Kaczyński reminded that "in the space of the last two hundred years, We, Poles, did not have too many opportunities to determine our lot independently. Rarely, had we a chance to set up a sovereign state, in which Poles - en block and each apart - might shape the standard of existence on their own. We have had this opportunity twice: in the times of the Second Polish Republic and after 1989 year"s.

2 KPRP, Polityka budowania prawdziwych autorytetów, $11^{\text {th }}$ November 2007, http:// www.prezydent.pl/archiwum/archiwum-aktualnosci/ [19.11.2011].

$3 \mathrm{KPRP}$, List prezydenta na odsłonięciu Pomnika Ofiar Komunizmu, 12 ${ }^{\text {th }}$ December 2009, http://www.prezydent.pl/archiwum/archiwum-aktualnosci/ [20.11.2011].

4 KPRP, Orędzie noworoczna Prezydenta RP, 31 ${ }^{\text {st }}$ December 2008, http://www. prezydent.pl/archiwum/archiwum-aktualnosci/ [22.11.2011].

5 KPRP, Prezydent: Państwo polskie musi stać się jeszcze silniejsze, $10^{\text {th }}$ November 2009, http://www.prezydent.pl/archiwum/archiwum-aktualnosci/ [19.11.2011]. 
The permanent reconstructing of History was the part of Kaczyński’s thinking about the Past groundwork. The Periodicity may be experienced at least in three different perspectives: firstly, during more than a thousand years of Polish statehood integrally; secondly, during the $20^{\text {th }}$ Century; and thirdly, with reference to effective social defiance against the enforced communist authorities in the time of the People's Republic of Poland. This national experience has fundamental meaning for Kaczyński's political concept, because it instructs that even [or first of all] in the time of stability and prosperity the Nation ought to expect returning, ravaging, and the worst possible Danger. Due to it Kaczyński's political goal was to establish enough strong state structure and enough close international alliances to be able to counteract all threats and as a result evade the next national enslavement, and successive generations' liberation struggle.

\section{THE REMEMBRANCE OF THE KATYŃ MASSACRE}

The majority, of President Kaczyński's interest in Polish History was enclosed in the $20^{\text {th }}$ Century, that was the sine wave including national ups and downs. Tragic struggles against Communist and Nazi totalitarian ideologies cost Poles the biggest price. Heroism and valor were insufficient against a material power and sinister expansion of two aggressors: German Nazis and Soviet. From both Polish society only encountered atrocity and cruelty, represented by Nazi genocidal politics of the Holocaust and Soviet extermination of Polish prisoners of war and civil servants in the Katyń Massacre ${ }^{6}$.

The Soviet hideous crime became one of the pillars of Kaczyński's politics of memory [that, as I have suggested before, was in the President's concept the basis of all state policies]; the Katyń Massacre was the end of a mythical time of the Sacred, the Calamity that demolished Proper Order,

6 KPRP, Prezydent: powinniśmy kontynuować proces upamiętniania ofiar, $17^{\text {th }}$ September 2009, http://www.prezydent.pl/archiwum/archiwum-aktualnosci/ [21.11.2011]; and KPRP, Prezydent w liście z okazji 91. rocznicy wybuchu Powstania Wielkopolskiego, 27th December 2009, http://www.prezydent.pl/archiwum/archiwum-aktualnosci/ [22.11.2011]. 
and forced the reestablishment of the whole cycle of History. Kaczyński's narration on the Massacre is overfilled by pain and suffering, and it is the only one, that the Polish President rehearsed, which did not contain the hope, and the faith in humanity at all.

Even though, the decline of interwar Poland symbolizes the end of freedom and independence, it continues to be evidence of a strong state, that brought up generations of brave patriots, and became an exemplar for following generations. The Shoah represents the end of Christian and humane values, the entire collapse of Humanism - but at the same time it reminds us about the courage and sacrifice of the Righteous among our Nation. The end of the 1944 Warsaw Uprising symbolizes the final demise of hopes for restoration of a democratic and independent Poland after World War II, however it was the heroic act of resistance against totalitarian ideology, and the constitution of patriotism and liberation struggle for the next generations. Finally, martial law in Poland closes the time of dreams and freedom, and ends the nationwide carnival of ,Solidarity', but yet the resistance to the authorities comes to an end with the decline of the People's Republic and progressive transformation.

Only the Katyń Massacre remains a wound, that cannot be healed. For Kaczyński it was overfilled by embitterment narration, and the reason for a distrust toward Russians, the legate of the maleficent and totalitarian heritage of Stalinism. But first and foremost, the President understood the Massacre as a symbolic, willful crime committed on the Polish Nation, that has never been judged and punished, and for almost half a century was the subject of a rousing lie.

The issue of the Katyń Massacre victims' commemoration was for Kaczyński a question of the first rank. In April 2008 he wrote: "the Katyń Massacre victims - the flower of the reborn Second Polish Republic played the highest price, that the Motherland could ever expect. Therefore, our duty is commemoration and honor to these thousands of heroes. And this historical remembrance is necessary for us, present Poles probably even more than for them"

\footnotetext{
7 KPRP, List Prezydenta RP do uczestników uroczystości upamiętniających mord
} 
In Kaczyński’s opinion the Massacre was Soviet vengeance for the Nation, that stopped the procession of Bolshevism in 1920 and restrained the communist plague after World War I. And it was not only a crime committed against this Nation, Joseph Stalin's aim was to destroy the patriotic tissue: civil servants, military commanders, and public officers, regardless of their nationality. Beside Poles, in the Katyń Massacre were murdered Belorussians, Germans, Jews and Ukrainians were murdered that all were united in love for freedom, and loyal service for the interwar Poland ${ }^{8}$.

Their 'guilt' was resistance against the maleficent Stalin dreams, and the wish to confront Great Russian chauvinism', and - what the Polish President stated just two days before his tragic death in the 2010 Polish Air Force Tu-154 Crash - "the Katyń 'death sentence' had to be a death sentence on the whole nation"10.

The Remembrance of the Katyń Massacre was for Kaczyński “an obligation towards those, who [...] expected families and friends, colleagues and subordinates in vain. It is a call to never forget their sacrifice, because it is and it will be a part of our common national identity"11. The example of implementing the Polish President's concept were ceremony "Katyń. Pamiętamy - Uczcijmy Pamięć Bohaterów" [en. "Katyń. We Remember - To Honor the Remembrance of Heroes"] in November 2007. During two days roll-call the list of this Soviet genocide, and on the President's

polskich oficerów, 13 ${ }^{\text {th }}$ April 2008, http://www.prezydent.pl/archiwum/archiwum-aktualnosci/ [19.11.2011].

8 KPRP, Pamiętajmy dalej, pamiętajmy w przyszłości”, $14^{\text {th }}$ April 2008; and KPRP, „Uroczystości w Katyniu, 17th September 2007, http://www.prezydent.pl/archiwum/archiwum-aktualnosci/ [18.11.2011].

9 KPRP, Wystąpienie Prezydenta RP pod pomnikiem Poległych i Pomordowanych na Wschodzie, 17th September 2009, http://www.prezydent.pl/archiwum/archiwumaktualnosci/ [21.11.2011].

10 KPRP, List prezydenta podczas obchodów 70. rocznicy Zbrodni Katyńskiej w Gorzowie Wlkp., $8^{\text {th }}$ April 2010, http://www.prezydent.pl/archiwum/archiwum-aktualnosci/ [22.11.2011].

11 KPRP, Ten akt ludobójstwa głęboko utkwił w świadomości naszego narodu, 29 ${ }^{\text {th }}$ March 2009, http://www.prezydent.pl/archiwum/archiwum-aktualnosci/ [21.11.2011]. 
own initiative all victims were posthumously promoted to a higher military and service rank ${ }^{12}$.

Reminding the Katyń Massacre Kaczyński disseminated the Remembrance of Soviet war crimes in Turza [today, a small village in Subcarpathian Voivodship], entitled 'the small Katyń' ${ }^{13}$, where in July 1944 Polish prisoners of war from the underground movement Armia Krajowa, interned in the Trzebuska prison camp, were slaughtered by Soviet People's Commissariat for Internal Affairs' [NKVD] special units. Kaczyński claimed to pay homage to heroes, that like the Katyn Massacre victims had to be killed just because they opposed against the expansion of the Stalinist totalitarianism ${ }^{14}$.

The tragedy of Soviet crimes towards Polish prisoners of war comes out as - similar to the Nazi's - dehumanization and depriving victims' dignity. Even though, before Polish and Soviet soldiers fought against a common enemy, jointly contributed to the final triumph over German Nazis, Soviet NKVD officers treated Polish combatants as unworthy soldier's death ${ }^{15}$. An assassination and omnipresent lie were inscribed into assumptions of the Stalinist state, without distinction if it was related to enemies, unfavorable neighbors, allied forces or its own citizens.

Kaczyński believed that international debat should be the symbolic representation of the Katyń Massacre and may undermine the influence of recognition of the Nazi totalitarian regime as the only case of Supreme Evil during the $20^{\text {th }}$ Century. He tried to prove that like German expansionism brought the tragedy of Shoah, Russian chauvinism also led to a magnitude of villainy. Kaczyński's endeavors for international recognition that the Katyń Massacre was a Crime of Genocide aimed at the remem-

12 KPRP, Prezydent RP wziął udział w uroczystościach „Katyń Pamiętamy - Uczcijmy Pamięć Bohaterów, 10 th November 2007, http://www.prezydent.pl/archiwum/archiwum-aktualnosci/ [18.11.2011].

13 This term is also used with reference to the 1945 Augustów Roundup.

14 KPRP, List prezydenta na uroczystościach mordu w Trzebusce, $20^{\text {th }}$ September 2009, http://www.prezydent.pl/archiwum/archiwum-aktualnosci/ [21.11.2011].

15 KPRP, List Prezydenta RP do uczestników i organizatorów uroczystości upamiętniających zbrodnię w Turzy, $16^{\text {th }}$ September 2007, http://www.prezydent.pl/ archiwum/archiwum-aktualnosci/ [19.11.2011]. 
brance of all Stalinist victims and showing the International Community how it may take effect on the concession policy in the case of reborn Russian imperialism.

The Polish President was not confined to the Remembrance of the Katyń Massacre or even all Polish victims of Soviet repressions - he reminded us of all Stalin's crimes during celebrations of the Holodomor [the genocide-famine in Ukraine between 1932 and 1933], supporting Baltic States' efforts to commemorate victims of communist crimes during World War II and after it. The paramount expression of his idea was his solidarity with Georgia and active support for this state during the 2008 Georgian-Russian War. In Tbilisi Kaczyński not only defended the attacked ally, he wanted to show that Russian ambitions can be suppressed just only thanks to the general objections of the International Community.

In Poland the President was accused of an anti-Russian, irrational phobia and pursuing unfounded policy against a powerful neighbour. Nevertheless Kaczyński believed that his concept was not constructed as an opposition to Russia, he perceived that Putin's transformation of the Post-Soviet Russian identity and repudiating Boris Yeltsin's assumption of the limited Power, and equal rank of all former Soviet states and challenging the Polish identity. That is, the Polish President thought that his policy was not anti-Russian, but it was established as anti-Russian because of Putin's idea of Russian regional supremacy.

Kaczyński in his speech during international celebrations of the $90^{\text {th }}$ Anniversary of the outbreak of World War II, to some extent addressing Russian Prime Minister Vladimir Putin, reminded that a united Europe achieved success thanks to two pillars of general agreement. First was the community of shared values: democracy, freedom, and pluralism, while second was a renunciation of hegemonic and imperial ambitions ${ }^{16}$. And from Russia he expected participating in this all-European agreement and respect for others identities and politics of memory, treating other nations as equivalent [alike not long ago Yeltsin did].

16 KPRP, Przemówienie Prezydenta na obchodach 70. rocznicy wybuchu II wojny światowej, $1^{\text {st }}$ September 2009, http://www.prezydent.pl/archiwum/archiwum-aktualnosci/ [22.11.2011]. 


\section{THE NEW FACE OF RUSSIAN IMPERIALISM}

In general, the question of Polish-Russian relations and apprehension of Russian expansionism [what of course cannot be surprising] were fundamental for Kaczyński's political concept. These problems were a 'realm' of his understanding of the Polish identity, and more extensively post-communist Central European identity; the Polish President believed that different historical experiences and distinct from West European understanding of the construction of Russian identity, obliged him to oppose not only Kremlin concepts, but equally West European efforts to deeper integrate Russia with the European Union.

Kaczyński comprehended the Russian state - through the whole of its history, from the Grand Duchy of Moscow - as an aggressive, expansionist, imperial, and invasive Power, that endangered its neighbours. In his concept 'being Polish', and 'being Central European' both meant to persist in spite of Russian thrusts; both of these identities were constructed with reference to counteracting Russian influences, and an objection to Russian dominance. In March 2008, hosting one of his closest political partners Georgian President Mikheil Saakashvili, Kaczyński noticed that the Georgian-Polish partnership was established on the grounds of affection for freedom and heritage of the struggle against Russian enslavement ${ }^{17}$.

Interviewed by American Fox News [just eight days after President Obama's cancellation of the emplacement of Ballistic Missile Defense [BMD] installations in Poland] Kaczyński asked about Russia, said that Russians always have the cheek to act in international politics. "If there is any occasion to do it, this state becomes even more audacious" - he warned ${ }^{18}$. Repeatedly, Kaczyński cautioned against the insatiability of Russian political elites, that may assume the totalitarian face, like it did in the times of the Stalinist crimes. He reluctantly received West European, cultural and political leaders' assumptions that the Absolute Dehumaniza-

\footnotetext{
17 KPRP, Polska wspiera przynależność Gruzji do NATO, $3^{\text {rd }}$ March 2008, http:// www.prezydent.pl/archiwum/archiwum-aktualnosci/ [20.11.2011].

18 KPRP, Wywiad prezydenta dla Fox News, 25 $5^{\text {th }}$ September 2009, http://www. prezydent.pl/archiwum/archiwum-aktualnosci/ [21.11.2011].
} 
tion can be only entered into the Nazi German identity and should not be applicable in the Russian case ${ }^{19}$.

Kaczyński also forewarned against overestimating the identity change that took place in Russia after the decomposition of the Soviet Union. In September 2008, during a Foreign Policy Association's conference, the Polish President reminded that the Russian "imperial tendency is slowly coming back to life in different ways; and the causes of this process are complicated. I suppose that the basic cause is this, what is entered into the heritage of a specific nation and state, what is the part of traditional relation between authorities and the society. [...] This tradition is contrary to the Transatlantic one. Finally, the cause is that the new governmental elite, appeared after communist times also emerged from the communist machinery. [...] This mentality remains and it is not a mentality of civic state"20.

In the President's case the antipathy towards contemporary Russian elites was not a result of incomprehensible prejudices, it resulted from a mythologized vision of its Eastern neighbour's imperialism. The expansionism that is - by its nature - anti-Occidental and distant from Euro-Atlantic constitutional values. That is why answering the current Secretary General of NATO Andres Fogh Rasmussen's suggestion that Russian membership in the Alliance is theoretically possible, Kaczyński stated that with regard of a contradiction between heritages and a different approach to execution the National Interest Russia should not ever become a member of NATO21.

A re-definition of Russian identity in the $20^{\text {th }}$ Century Kaczyński followed anxiously. He believed that Russia may be an important and reliable neighbour, and a solid partner for the European Union. However, other than French, German or Italian political leaders, treating Dmitry Medvedev and Vladimir Putin as democratic politicians from an influential regional Power, the Polish President preferred to recognize them as successors of the Soviet Establishment.

19 KPRP, Wizyta Prezydenta RP na Ukrainie, 22 ${ }^{\text {nd }}$ November 2008, http://www. prezydent.pl/archiwum/archiwum-aktualnosci/ [20.11.2011].

20 KPRP, NATO to eksporter stabilizacji i pokoju, $24^{\text {th }}$ September 2009, http://www. prezydent.pl/archiwum/archiwum-aktualnosci/ [21.11.2011].

21 KPRP, W Belwederze o Afganistanie i Rosji, 12 ${ }^{\text {th }}$ March 2010, http://www. prezydent.pl/archiwum/archiwum-aktualnosci/ [23.11.2011]. 
In November 2008 applying to the President of the European Commission Jose Manuel Barroso Kaczyński wrote that "for us it cannot be meaningless on the basis of how Russia constructs its future. We have the right to expect that Russia, benefiting from intensive relations with the EU member-states, should respect values, that constitutes our community. [...] If we eliminate nationalism from European societies, we may anticipate that Russian authorities will not tolerate it, all the more will not locate it in the center of the state's ideology"22.

Kaczyński paid remarkable attention to Polish Energy Security, and that made him interested in Russian natural gas imperialism. The struggle against, energetic blackmail' was one of the main aims of the Kaczyński's Presidency and the goal for all the Central European alliance, that he wished to establish ${ }^{23}$. He realized that the future security of Poland depends on the elimination of menace from renascent Russian expansionism; and Kaczyński considered that it requires - firstly - diversification of energetic resources supplies, and - secondly - strengthening the NATO presence in Central Europe ${ }^{24}$.

Besides the desire of constructing a modern and safe Poland, the danger of Russian 'energetic blackmail' was the main reason for Kaczyński’s concept of an energy policy. Ukrainian experiences in 2006 and cutting off [or drastic limitation of] natural gas' supplies to Austria, Bulgaria, Croatia, FYROM, Greece, Hungary, Turkey, and Ukraine in 2009 showed Kaczyński how helpless a state can be in the face of political usage controlled by the Russian government OAO Gazprom. Simultaneously, the President was worried about Polish Energy Security because of the German-Russian Nord Stream pipeline project [that sometimes was paralleled

22 KPRP, List Prezydent RP do Przewodniczącego Komisji Europejskiej, $26^{\text {th }}$ November 2008, http://www.prezydent.pl/archiwum/archiwum-aktualnosci/ [20.11.2011].

23 KPRP, Lech Kaczyński, Wiktor Juszczenko, Mirek Topolanek: Kryzys gazowy się jeszcze nie skończył, 28 ${ }^{\text {th }}$ January 2008, http://www.prezydent.pl/archiwum/archiwumaktualnosci/ [19.11.2011]; and KPRP, Wywiad Prezydenta RP Lecha Kaczyńskiego dla agencji Reuters, $24^{\text {th }}$ September 2009, http://www.prezydent.pl/archiwum/archiwumaktualnosci/ [22.11.2011].

24 KPRP, Prezydent w "New York Times" [The New York Times' interview with Lech Kaczyński], 12 $2^{\text {th }}$ March 2009, http://www.prezydent.pl/archiwum/archiwum-aktualnosci/ [21.11.2011]. 
with the 1939 Molotov-Ribbentrop Pact, dividing Northern and Central Europe into German and Soviet spheres of influence].

They were all thereasons of Kaczyński's fear of a new international deal, dividing the World into areas of Power's domination. Sore experiences of Russian chauvinism and expansionism, communist ancestry of the current Russian establishment, successful usage of OAO Gazprom's 'energetic blackmails' in 2006 and 2009, building a pipeline passing through the Baltic Sea, that increase European energy dependence on Russia, and at last Russian military support for separatist republics in Georgia were, in Kaczyński's opinion, arguments for his concept of counteracting an increase of the Kremlin influences in Poland and the European Union.

Nonetheless, the stab in the back came from the White House; President Barack Obama's decision to cancel emplacement BMD installations in the Czech Republic and Poland was made under unambiguous Russian pressure. But the date of announcing American abdication was symbolic and extremely sore - it was obvious that the results of the US President's decision made $17^{\text {th }}$ September 2009 would be compared with the 1939 Soviet invasion of Poland that was exactly seventy years before. Kaczyński who was describing German and Soviet annexing of Polish territories as a destruction of 'divine time' of the interwar Poland all the more felt offended by Obama's lack of respect for Polish history and his confession in relations with Russia ${ }^{25}$.

\section{THE TRIAL OF COURAGE}

The mistrust in relations with Russia was the groundwork of Kaczyński's political concept and from this point of view he selected his closest allies. But in most cases it was just a supplementary and dispensable factor: with Lithuanian President Valdas Adamkus connected him to a community of values and anti-communist attitude, with Ukrainian President Victor

25 KPRP, Wystąpienie Prezydenta RP w Metropolitan Club w Nowym Jorku, 25 ${ }^{\text {th }}$ September 2009, http://www.prezydent.pl/archiwum/archiwum-aktualnosci/ [21.11.2011]. 
Yushchenko a desire to extend the European community over Post-Soviet states, with Czech President Vaclav Klaus a euro-skeptic. The connection between Kaczyński and Georgian President Mikheil Saakashvili resulted from a common comprehension of Russian imperialism.

The Georgian leader - although not devoid of weaknesses - in Kaczyński's vision grew as a symbol of resisting the Kremlins expansionism. Both of the politicians recognized present-day Russian authorities as successors of a sinister Tsarist and Soviet regime, that instead of cruel colonization, dislocations, and genocide practices applies economic dependence, bribery, and the 'passport policy'. They believed that even though, after the Dissolution of the Soviet Union, methods have changed, the dreams of Russian supremacy. And this bond between Kaczyński and Saakashvili was made possible by the Polish President's moment of glory, which was his unforgettable speech in Tbilisi during the 2008 Georgian-Russian War. The speech, in which Kaczyński paraded his own understanding of the Kremlin intentions and the way to restrain Russian expansionism.

The relationship between the two presidents requires a short comment. Anti-Russian view was the cornerstone of their partnership, that soon included other common grounds. Kaczyński fully supported Georgian aspirations to become a member of NATO and the European Union, whereas Saakashvili returned his kindness actively taking part in a Polish project of the former communist state's close alliance. Both president's visions of the international security in the $21^{\text {st }}$ Century were based on two assumptions: Russian chauvinism and expansionism danger, and understanding the United States' [and NATO as a whole] identity as the only Superpower that may be a guarantor of development, peace and stability in international relations. Additionally, Kaczyński and Saakashvili shared a deep patriotism and the respect of freedom fighters - national heroes, that was noticeable during the $62^{\text {nd }}$ Anniversary of the 1944 Warsaw Uprising ${ }^{26}$.

Although, the presidents were close allies, what was characteristic for their relationship was a bond of mutual amity. After Saakashvili's electoral victory in January 2008 Kaczyński openly stated his individual satisfaction,

26 KPRP, Spotkanie Prezydenta RP z Prezydentem Gruzji, $2^{\text {nd }}$ August 2006, http:// www.prezydent.pl/archiwum/archiwum-aktualnosci/ [17.11.2011]. 
and respect for the Georgian politician and the far-sightedness of the Georgian Nation. Observing the establishment of democracy in this South Caucasian state, Kaczyński appreciated that Georgia was neither following Polish transformation, nor the Ukrainian one, where [in both cases] the internal disruption of democratic forces and fraternization with old political elites made authentic and comprehensive restoration of the state impossible. He believed that Georgia thanks to Saakashvili may evade a dispelling of national hope ${ }^{27}$.

As it was mentioned before, Kaczyński took advantage of History to motivate his political concept - sore experiences with Russian imperialism made him suspicious towards the Kremlin authorities, while heritage of the anti-Russian struggle entailed his fellow feeling for the Georgian Nation. In March 2008 supporting NATO's Membership Action Plan for Georgia he called up common inheritance of anti-Totalitarian values, mutual understanding of the Georgian and Polish nations, and both nations' congenital aspirations ${ }^{28}$. During official appointments with Saakashvili he reminded the Georgian voluntary soldiers' participation in the struggle for Polish Independence ${ }^{29}$, their death in the Katyń Massacre, and courage and sacrifice during the 1944 Warsaw Uprising ${ }^{30}$.

There were three main reasons why Kaczyński reacted in so unequivocal way to Russian military operations against Georgia in 2008. First was - described above - his personal bond with Saakashvili and respect for the proud Georgian Nation. However there were two other ones. He really believed that his obligation was to counteract Russian hegemony in Central and Eastern Europe, and he - due to it - presumed that the breakage of Georgia would in the near future mean the Russian enslavement of the whole Post-Soviet area. Kaczyński was also guided by the interwar and

27 KPRP, Wizyta Prezydenta RP w Gruzji, $20^{\text {th }}$ January 2008, http://www.prezydent. $\mathrm{pl} /$ archiwum/archiwum-aktualnosci/ [20.11.2011].

28 KPRP, Polska wspiera przynależność Gruzji w NATO, $3^{\text {rd }}$ March 2008, http://www. prezydent.pl/archiwum/archiwum-aktualnosci/ [20.11.2011].

29 KPRP, Wizyta Prezydenta RP w Gruzji, 23 ${ }^{\text {rd }}$ November 2007, http://www. prezydent.pl/archiwum/archiwum-aktualnosci/ [19.11.2011].

30 KPRP, Wizyta Prezydenta Gruzji w Polsce, 10 ${ }^{\text {th }}$ May 2007, http://www.prezydent. $\mathrm{pl} /$ archiwum/archiwum-aktualnosci/ [19.11.2011]. 
Poland's mythical Testament, that made him a promoter and representative of the self-reliant alliance of Central and Eastern European states. In Tbilisi he was not just an ally meeting his own obligations, he was the one who opened and read the interwar Poland's Will.

With no doubts, Kaczyński's involvement in the 2008 Georgian-Russian War was the culminating point of his Presidency. That day he articulated his political concept and the whole political World was focused its attention on him, and his opinions. Kaczyński proved his courage and devotion to values, that he tried to incorporate into the Polish national identity and the international Discourse.

On the $9^{\text {th }}$ August 2008, soon after the beginning of the War, Kaczyński stated: "The last 48 hours has deepened the crisis in Abkhazia and South Ossetia in a degree that we so far [...] have not expected. What happened is the upfront intervention in an exterior territory. [...] As a matter of fact Russian Federation Forces' action is the Act of Aggression" 31 . Immediately regional political leaders, presidents: Estonian Toomas Hendrik Ilves, Latvian Valdis Zatlers and Lithuanian Adamkus gave him their support. Also the Ukrainian President Yushchenko soon joined the anti-Russian initiative.

Three days later on Freedom Square in Tbilisi Kaczyński delivered his most memorable speech. He said: "We are here to express our solidarity. [...] We are here to take up the gauntlet. For the first time for years our neighbour $[\ldots]$ showed his face, which we have known for centuries. This neighbour thinks that adjoining nations have to be subordinate to it. We say: no! This state is Russia. This state considers that former times of bankruptcy - less then 20 years ago - the Empire has returned. It thinks that a dominance will be a regional characteristic once again. Well it will not be. Those times have ended once and for all. [...] We all experienced this dominance either at the same time or in different periods. It is a calamity for the whole of Europe. [...] Today, the World has to react, even

31 KPRP, O Gruzji w Pałacu Prezydenckim, 9 ${ }^{\text {th }}$ August 2008, http://www.prezydent. pl/archiwum/archiwum-aktualnosci/ [20.11.2011]. 
if it is unwilling to do so. And we are here to make the World's responce more intensive" 32 .

During his speech in Tbilisi Kaczyński symbolically came into the Polish National Myth of the Freedom Struggle. For the short time he joined those, who were opposed to enslavement, and had taken up the gauntlet without fear of the possible consequences. Recalling the picture of Russia he reminded that Nazi Germany was not the only one that was Pure Evil in the $20^{\text {th }}$ Century, but the communist Soviet Union was one and the same. Showing the face of Russian imperialism he was proving that Central and Eastern European states could evade a disaster only if it were united [what was in Kaczyński's opinion impossible by oneself].

The Polish President has crossed a line separating pragmatic politics from constructed values of imagination of the ,perfect' World [that is why, after his death Saakashvili noticed that like Otto von Bismarck gave future generations the concept of Realpolitik, Kaczyński left the concept of moral-politics ${ }^{33}$. In Tbilisi he struggled against Russian imperialism like protectors of the Christian Civilization during the Bolshevik-Polish War, like soldiers fighting against the Totalitarianism on all Fronts of World War II, like heroic Warsaw insurgents, and like 'cursed soldiers' of the anti-communist underground. Again, like during the carnival of 'Solidarity', Kaczyński defended the Weaker, and its dignity and freedom. He took the side of values, which were fundamental for his political concept: courage, freedom, justice, patriotism, sacrifice for ultimate goals, and solidarity.

During the 2008 Georgian-Russian War Kaczyński passed his trial, and he experienced his days of glory. Probably, if the Polish President had not died in the 2010 Polish Air Force Tu-154 Crash, his speech in Tbilisi would be the most important and the most memorable occurrence of his Presidency.

32 KPRP, Wizyta Prezydenta RP w Gruzji, 12 ${ }^{\text {th }}$ August 2008, http://www.prezydent. pl/archiwum/archiwum-aktualnosci/ [20.11.2011].

33 M. Saakashvili, Hołd Pamięci Przyjaciela, [in:] Lech Kaczyński. Portret, ed. M. Karnowski, Kraków 2010, p. 252. 


\section{DILEMMAS OF THE POLISH-RUSSIAN RECONCILIATION}

I already noticed that the understanding of the Katyń Massacre made President Kaczyński mistrustful in relations with Russia. I also mentioned how his comprehension of national History led him to endeavors to establish self-reliant alliances of former communist states in Central and Eastern Europe. And if his foreign policy concept was founded on the fear of Russian expansionism [next to the fear of German domination in the European Union, and trust in the United States as a guarantor of freedom, peace, and stability], is it even possible that Kaczyński desired the PolishRussian Reconciliation?

It is more than certain that he did. However this atonement was - in Kaczyński's opinion - impossible until the Russian authorities reject the Superpower hegemonic identity, chauvinism and imperial tendencies. The way of restoring Russian status in international relations, which Putin chose the Polish President could not accept.

The increase of imperialist tendencies in the Kremlin foreign policy, their ,energy blackmail' strategy and the military operation to divide allied Georgia were in Kaczyński's vision only examples of a rebirth of the real Russian identity, that he knew from the Past. It is characteristic for the President that setting up his political manifestos was guided by historical experiences, and through this prism he glanced at the Present. His attitude to the 2008 Georgian-Russian War, and his commemoration of the Katyn Massacre victims [and other victims of communist repressions] were Kaczyński’s own tribute to generations of Polish patriots.

Already on 23rd December 2005, the day of Solemn Oath the Polish President delivered a speech addressed to the National Assembly, in which he stated that with reference to Polish-Russian relations it is necessary to be patient, but never to disavow sore experiences of the Past ${ }^{34}$. Kaczyński claimed the Remembrance, and the Rehabilitation for victims of Soviet crimes: the Katyń Massacre; NKVD ,troikas', and other Soviet instruments

34 KPRP, Uroczystość zaprzysiężenia Prezydenta RP Lecha Kaczyńskiego przed Zgromadzeniem Narodowym, $23^{\text {rd }}$ December 2005, http://www.prezydent.pl/archiwum/archiwum-aktualnosci/ [17.11.2011]. 
of extrajudicial punishment; Mass Deportations to the East [mostly to Siberia and Kazakhstan], and forced labour camps [the Gulag System] ${ }^{35}$.

The 'Russian Evil' was in the President's opinion an identical twinbrother of the Nazi one. Communist ideology was - like Hitler's national socialism - an entire denial of Christian and Human values, that constituted contemporary Europe. The Polish-Russian atonement was only possible on the groundwork of the European Civilization, therefore a mutual renunciation of the Bolshevik and Soviet heritage and commemorating victims of this regimes' crimes. Without common Remembrance of the sore Past rapprochement between two nations could not be attainable ${ }^{36}$. But in Kaczyński's opinion, to make a common Remembrance attainable Russia should change its own identity and ultimately break with the tradition of diktat, and unequal treating of adjoining states, and pure and simply after this reconstruction dealing with the History would be possible ${ }^{37}$.

In his interview for "Super Express" Kaczyński stated: "the respect in relations with our neighbour means also the courage to face the truth, when this neighbour is departed from it. It is necessary to do it in the name of our Memory. But above all for our Future. Only the Truth [...] can be a solid groundwork for Reconciliation" ${ }^{38}$. Two months before his untimely death the President wrote: "we do not call up [...] suffering in the spirit of rancor or the lust for revenge. We know that History [...] should not barricade our way to dialogue and atonement" 39 . Kaczyński truly believed that friendly relations between Poland and Russian could established only

35 KPRP, Wystąpienie Prezydenta RP pod pomnikiem Poległych i Pomordowanych na Wschodzie, 17th September 2009, http://www.prezydent.pl/archiwum/archiwumaktualnosci/ [21.11.2011].

36 KPRP, Oddajemy hołd ofiarom zbrodni katyńskiej, $5^{\text {th }}$ March 2010, http://www. prezydent.pl/archiwum/archiwum-aktualnosci/ [22.11.2011].

37 KPRP, Prezydent o reakcjach Rosji nt. uchwały Sejmu ws. 17 września, 24 $4^{\text {th }}$ September 2009, http://www.prezydent.pl/archiwum/archiwum-aktualnosci/ [21.11.2011].

38 KPRP, Lech Kaczyński: Potrzebujemy solidarności, $5^{\text {th }}$ September 2009, http:// www.prezydent.pl/archiwum/archiwum-aktualnosci/ [21.11.2011].

39 KPRP, List prezydenta z okazji 70. rocznicy Martyrologii Polaków na Wschodzie, $10^{\text {th }}$ February 2010, http://www.prezydent.pl/archiwum/archiwum-aktualnosci/ [22.11.2011] 
through the Truth and mutual commemorating of sore experiences of the Past. But he did not want to achieve the Reconciliation at any price: firstly, he wanted to strengthen the Polish identity, secondly, to establish a selfreliant Central European alliance, and after that he wished to come to an agreement with the Kremlin authorities.

\section{EPILOGUE}

It is evident that the core of Lech Kaczyński's political concept was anti-Russian. Interpreting the Past the Polish President was afraid that an increase of Kremlin expansionism in Putin's era would result in the next national and regional tragedy, like the Katyń Massacre. Only the Myth of the 1944 Warsaw Uprising is comparable [as the most powerful] with the narration about Soviet crimes committed on the Polish nation. However, Kaczyński reminded that this community of suffering unites Poles with other nations enslaved by the Stalinist Soviet Union - victims of communism are not only the Polish, but also a few million Russian and other nationalities.

The Symbol of this, hell of communism' is the Katyn Grave, where close to where Polish patriots were buried - killed by NKVD officers - Belorussians, Jews, Latvians, Russians and Ukrainians ${ }^{40}$. Similarly, lots of Polish exiles to Siberia and their local, indigenous neighbours are the Symbol of the Russian repression of other nations, and Kaczyński referred to their inheritance, recognizing the Sybirak Union's motto: "Remembrance for the Deceased, Reconciliation for the Living" as the challenge of his Presidency ${ }^{41}$. The groundwork of the common sore of History was - in Kaczyński's concept - the only one indefeasible principle of a cooperation between nations, especially with reference to the Future of the Polish-Russian Reconciliation.

40 KPRP, Uroczystości w Katyniu, 17th September 2007, http://www.prezydent.pl/ archiwum/archiwum-aktualnosci/ [18.11.2011].

41 KPRP, List Prezydenta RP skierowany do organizatorów i uczestników uroczystości VIII Międzynarodowego Marszu Żywej Pamięci Polskiego Sybiru, $11^{\text {th }}$ September 2008, http://www.prezydent.pl/archiwum/archiwum-aktualnosci/ [20.11.2011]. 